\title{
PENYULUHAN ANTI BULLYING PESERTA DIDIK
}

\author{
Ika Murtiningsih ${ }^{1}$, Toni Harsan ${ }^{2}$, Pujiyana $^{3}$, Pranowo ${ }^{4}$, Siti Fatimah ${ }^{5}$ \\ Program Studi PPKn Fakultas Keguruan dan Ilmu Pendidikan \\ Universitas Veteran Bangun Nusantara \\ Email: ika.murtyy@gmail.com ${ }^{1}$
}

\begin{abstract}
Abstrak
Permasalahan di sekolah yaitu perilaku bullying yang mengarah pada tindakan mengejek, menyuruh, memalak, mendiskriminasi, dan bahkan terjadi pemukulan. Beberapa faktor diyakini menjadi penyebab terjadinya bullying adalah faktor sosial ekonomi, perbedaan fisik, dan perbuatan masa lalu yang dilakukan. Dampak yang ditimbukan dari kejadian bullying yaitu penurunan prestasi belajar, sering bolos sekolah, mengundurkan diri dari sekolah, dan bahkan putus sekolah. Penyuluhan anti bullying bertujuan agar peserta didik dapat mengantisipasi perilaku yang mengarah pada tindakan mengejek, menyuruh, memalak, mendiskriminasi, dan pemukulan. Penyuluhan dilaksanakan di Sekolah Menengah Kejuruan Batur Jaya 1 Ceper Klaten. Penyuluhan anti bullying dilakukan dengan metode ceramah dan diskusi. Penyuluhan dilakukan selama 3 jam dan diikuti oleh peserta didik sebanyak 30 orang. Bentuk evaluasi menggunakan pre test dan post test. Hasil pre test menyatakan bahwa pengetahuan peserta didik mengenai bullying sangat minim yaitu $30 \%$. Sedangkan hasil setelah dilakukan post test, maka pengetahuan peserta didik meningkat menjadi $85 \%$. Keberhasilan ini dapat diukur dengan banyaknya peserta didik yang mau dan berani bertanya dan memecahkan masalahnya, serta juga bisa dilihat dari kepuasan peserta setelah mengikuti kegiatan, sehingga memotivasi peserta didik untuk menghindari dan tidak melakukan tindakan bullying di sekolah.
\end{abstract}

Kata Kunci: Penyuluhan, Anti Bullying, Peserta Didik

\begin{abstract}
The problem at school is bullying behavior which leads to mocking, ordering, yelling, discriminating, and even beatings. Several factors are believed to be the cause of bullying, namely socioeconomic factors, physical differences, and past actions that were committed. The impact of bullying is a decrease in learning achievement, frequent skipping school, resigning from school, and even dropping out of school. Anti-bullying counseling aims so that students can anticipate behavior that leads to mocking, ordering, yelling, discriminating, and beatings. The counseling was held at the Batur Jaya 1 Ceper Klaten Vocational High School. Anti-bullying counseling is carried out using lectures and discussions. Extension was carried out for 3 hours and was attended by 30 students. Form of evaluation using pre test and post test. The results of the pre-test stated that the students' knowledge of bullying was minimal, namely 30\%. While the results after the post test, the students' knowledge increased to $85 \%$. This success can be measured by the number of students who are willing and brave to ask questions and solve problems, and can also be seen from the satisfaction of participants after participating in the activity, thus motivating students to avoid and not commit bullying at school.
\end{abstract}

Keywords: Counseling, Anti Bullying, Students

\section{PENDAHULUAN}

Berdasarkan Rosen, DeOrnellas dan Scott (2017) bullying merupakan perilaku agresif yang dilakukan oleh remaja atau kelompok remaja yang tidak bersaudara yang memiliki kekuatan yang tidak seimbang dan berulang-ulang. Sedangkan menurut Migliaccio dan Raskauskas (2016) bullying merupakan perilaku agresi yang menyebabkan distress dan ketidaknyamanan bagi orang lain yang terjadi di seluruh sekolah di dunia. Bullying memiliki beberapa karakteristik yaitu selalu dilakukan berulang-ulang, memiliki niat untuk menyakiti, dan perbedaan kekuatan. Biasanya bullying dilakukan pihak yang lebih kuat terhadap pihak yang lebih lemah. Tindakan penindasan tersebut dapat diartikan sebagai penggunaan kekuasaan atau kekuatan untuk menyakiti seseorang atau sekelompok orang sehingga korban merasa tertekan, trauma, dan tidak berdaya. 
Apabila hal ini terjadi di lingkungan sekolah, maka akan berdampak pada prestasi belajar peserta didik di sekolah.

Perilaku bullying yang terjadi di lingkungan sekolah akhir-akhir ini sangat memprihatinkan bagi pendidik dan orangtua. Perilaku bullying di lingkungan sekolah banyak beredar di media massa. Dalam hal ini sekolah harus menjadi peran utama dalam mengantisipasi perilaku bullying, sebab kebanyakan kasus justru sekolah menjadi tempat praktek-praktek bullying. Apabila dibiarkan maka akan berdampak pada perkembangan karakter peserta didik. Hal ini sesuai dengan hasil penelitian Sejiwa (2008) menyebutkan bahwa sebagian kecil guru (27\%) menganggap bullying merupakan perilaku normal dan sebagian besar guru (73\%) menganggap bullying sebagai perilaku yang membahayakan peserta didik. Hal tersebut tidak bisa dianggap normal karena peserta didik tidak dapat belajar apabila peserta didik berada dalam keadaan tertekan, terancam, dan ada yang menindasnya setiap hari.

Hal tersebut diperkuat dengan hasil penelitian oleh Schneider, et al. (2012) menunjukkan bahwa korban bullying memiliki tingkat tekanan mental yang lebih tinggi, dengan kejadian depresi dan keinginan bunuh diri masing-masing sebesar $4.38 \%$ dan 5.35\%. Korban bullying juga disebutkan mengalami penurunan prestasi belajar di sekolah dan lebih sering absen dari sekolah (Schneider, et al, 2012). Selaras dengan hasil penelitian tersebut, kejadian yang sering terjadi di SMK Batur Jaya 1 Ceper Klaten bahwa siswa korban bullying dalam keadaan yang tertekan dan terancam sehingga berakibat pada penurunan prestasi belajar, sering bolos sekolah, mengundurkan diri dari sekolah, dan bahkan putus sekolah.

Adapun bentuk-bentuk bullying yang sering terjadi yaitu mengejek, menyuruh, memalak, mendiskriminasi, dan bahkan terjadi pemukulan. Tindakan-tindakan ini apabila dilakukan secara terus menerus akan menjadikan korban bully menjadi depresi akibat tekanan mental yang dilakukan secara dinamis dan berulang. Beberapa faktor diyakini menjadi penyebab terjadinya bullying adalah faktor sosial ekonomi, perbedaan fisik, dan perbuatan masa lalu yang dilakukan. Hal inilah mendorong perlu dilaksanakan penyuluhan anti bullying guna membekali para peserta didik mengantisipasi adanya tindakan bullying di sekolah.

\section{METODE KEGIATAN}

Metode yang digunakan dalam Pengabdian Kepada masyarakat dengan tema penyuluhan anti bullying adalah metode ceramah dan diskusi. Penyuluhan ini ditujukan agar materi anti bullying dapat tersampaikan secara lengkap dengan waktu yang tersedia. Dengan demikian, peserta didik dapat mengantisipasi adanya perilaku-perilaku bullying di sekolah. Sehingga peserta didik dapat membangun pengetahuan dan kesadaran akan bahaya bullying di lingkungan sekolah. Penyuluhan akan dilakukan selama 2 jam dan diikuti oleh peserta didik sebanyak 30 orang. Bentuk evaluasi yang akan digunakan adalah pre test dan post test. Hal ini dilakukan untuk mengetahui pemahaman materi yang telah diberikan kepada peserta didik guna mengantisipasi adanya perilaku bullying yang dilakukan di lingkungan sekolah.

\section{HASIL DAN PEMBAHASAN}

Kegiatan penyuluhan anti bullying peserta didik di SMK Batur Jaya 1 Ceper dilaksanakan pada hari Jumat, 10 Juli 2020 dari jam 08.30 WIB s.d 11.00 WIB, dengan diikuti oleh 30 peserta didik (terlampir). Kegiatan yang dilakukan berupa pre test, penyampaian materi, dan post test. Peserta didik yang menghadiri tampak sangat antusias dalam mengikuti semua kegiatan dari awal hingga akhir.

Pengetahuan peserta didik mengenai bullying sangat minim hal itu terlihat saat sesi pre test peserta didik terlihat minim pengetahuan mengenai bullying dan mereka tidak mengetahui dampak yang ditimbulkan apabila bullying dilakukan secara terus menerus dapat mengakibatkan gangguan emosional dan psikologis. Bahkan terdapat beberapa peserta didik yang sering 
melakukan bullying kepada temannya di kelas, dimana dampaknya penurunan semangat belajar hingga terdapat peserta didik yang keluar sekolah karena ketakutan kepada pelaku bullying. Pengetahuan peserta didik mengenai anti bullying hanya sebesar $30 \%$.

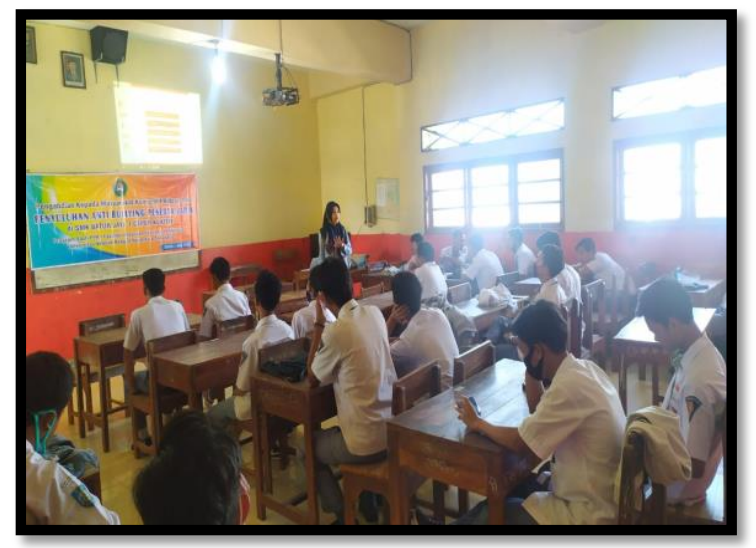

Gb. 1 Foto Penyampaian Materi

Materi-materi yang disampaikan kepada peserta didik yaitu pertama, pengertian bullying, Bullying merupakan perilaku agresif yang dilakukan oleh individu maupun sekelompok orang yang dilakukan berulang-ulang dan menjadi penyebab potensi kekerasan dan masalahmasalah lain. Perilaku agresif yang ditunjukkan peserta didik tersebut berpotensi untuk dilakukan secara berulang-ulang baik di sekolah dan masyarakat (Putri, Nauli \& Novayelinda, 2015). Hal ini didukung oleh pernyataan Djuwita (2006) bahwa Bullying adalah penggunaan kekuasaan atau kekuatan untuk menyakiti seseorang atau sekelompok, sehingga korban merasa tertekan trauma, dan tidak berdaya, dan peristiwinya mungkin terjadi berulang. Perilaku bullying kurang mendapat perhatian baik dari sekolah, masyarakat, dan pemerintah, sehingga perilaku ini terus dilakukan oleh remaja. Perilaku bullying harus dipecahkan secara bersama-sama sebab menurut beberapa peneliti (dalam Veenstra et al, 2005) bullying mengakibatkan beberapa ancaman serius terhadap perkembangan peserta didik di sekolah. Pelaku bullying beresiko tinggi untuk terlibat dalam kenakalan remaja dan kriminalitas. Sedangkan ancaman terhadap korban bullying yaitu beresiko tinggi mengalami depresi dan stress yang dapat menimbulkan trauma.

Kedua, kategori bullying yang terdiri atas, kontak fisik langsung (memukul, mendorong, mencaar), kontak verbal langsung (mengancam, merendahkan, memberi panggilan nama (name calling) mempermalukan,mengejek dII), perilaku non verbal langsung (melihat dengan sinis, menjulurkan lidah, menampilkan ekspresi muka), perilaku non verbal tidak langsung (mendiamkan, mengucilkan mengirim surat kaleng), pelecehan seksual (kadang dikategorikan perilaku agresi fisik atau verbal).

Materi ketiga yaitu faktor-faktor penyebab terjadinya bullying yaitu faktor internal (dendam, terhina, tertekan, dsb), dan faktor eksternal yakni lingkungan keluarga, lingkungan sekitar rumah, lingkungan sekolah, media massa, dan media cetak. Faktor eksternal berupa keluarga yang tidak harmonis, sering berkelahi, guru dan teman di sekolah berbuat kasar dan kurang perhatian, meniru perilaku dari media massa, tuntutan korformitas teman sebaya, dan lingkungan sosial budaya. Pola hidup orang tua yang berantakan, terjadi perceraian orang tua, orang tua tidak stabil perasaan dan fikirannya, kemauan dan tingkah lakunya, orang tua saling mencaci maki, menghina, bertengkar dihadapan anak-anaknya, bermusuhan dan tidak pernah akur, memicu munculnya depresi dan strees bagi anak, (Kartono, 2003: 31). Hal ini memicu terjadinya depersonalisasi terhadap anak sehingga menjadikan pribadi yang mempunyai perilaku menyimpang seperti bully. 
Tanda-tanda anak korban bullying yaitu kesulitan dalam bergaul, merasa takut datang ke sekolah, sehingga sering bolos sekolah, ketinggalan pelajaran, mengalami kesulitan berkonsentrasi dalam mengikuti pelajaran, dan kesehatan fiisk dan mental (jangka pendek/jangka panjang) akan terpengaruh. Terdapat tiga dampak yang ditimbulkan yaitu dampak fisik (sakit kepala, sakit dada), dampak pesikologis (emosi negatif seperti marah, dendam, kesal, tertekan, takut, malu, sedih), dan dampak pskikologis ekstrim (rasa cemas berlebihan, ingin bunuh diri). Strategi mengatasi bullying yaitu memupuk pemahaman agama yang baik dan menjaga komunikasi antar teman dan keluarga, mengembangkan kecerdasan emosional, menyadarkan anak sebagai makhluk sosial, adanya kebijakan menyeluruh di sekolah, dan membuat programprogram anti bullying yang dapat mencegah terjadinya kejadian-kejadian bully di sekolah.

Apabila dikaitkan bullying dengan kekerasan dalam Undang-Undang Perlindungan Anak, maka dapat disimpulkan bahwa perilaku atau tindakan bullying termasuk dalam bentuk kekerasan terhadap anak. Sebagaimana dalam pasal 1 angka 16 UU Nomor 35 Tahun 2014 tentang Perubahan atas UU Nomor 23 Tahun 2002 tentang perlindungan anak, disebutkan bahwa kekerasan adalah setiap perbuatan terhadap anak yang berakibat timbulnya kesengsaraan atau penderitaan secara fisik, psikis, seksual dan/atau penelantaran, termasuk ancaman untuk melakukan perbuatan, pemaksaan, atau perampasan kemerdekaan secara melawan hukum.

Berdasarkan pada bunyi pasal di atas, dapat disimpulkan bahwa perilaku atau tindakan bullying adalah bentuk kekerasan terhadap anak yang termasuk ke dalam tindak pidana yang mana terhadap pelaku bullying dapat dikenakan sanksi pidana sebagaimana disebutkan dalam Pasal 80 ayat (1) UU Nomor 35 tahun 2014 jo Undang-Undang Nomor 23 Tahun 2002 tentang Perlindungan Anak yang berbunyi sebagai berikut:

Setiap orang yang melanggar ketentuan sebagaimana dimaksud dalam Pasal 76C, dipidana dengan pidana penjara paling lama 3 (tiga) tahun 6 (enam) bulan dan/atau denda paling banyak Rp72.000.000,00 (tujuh puluh dua juta rupiah)." Sedangkan Pasal 76C UU 35/2014: "Setiap Orang dilarang menempatkan, membiarkan, melakukan, menyuruh melakukan, atau turut serta melakukan Kekerasan terhadap Anak.

Selain mengatur tentang ancaman pidana bagi pelaku kekerasan bullying, UU No. 35 Tahun 2014 jo UU No. 23 Tahun 2002 tentang Perlindungan Anak juga mengatur tentang perlindungan anak dari tindak kekerasan di sekolah, sebagaimana disebutkan dalam Pasal 54 seperti berikut:

1) Anak di dalam dan di lingkungan satuan pendidikan wajib mendapatkan perlindungan dari tindak Kekerasan fisik, psikis, kejahatan seksual, dan kejahatan lainnya yang dilakukan oleh pendidik, tenaga kependidikan, sesama peserta didik, dan/atau pihak lain.

2) Perlindungan sebagaimana dimaksud pada ayat (1) dilakukan oleh pendidik, tenaga kependidikan, aparat pemerintah, dan/atau masyarakat.

Pernyataan di atas jelas bahwa pendidik, tenaga kependidikan, aparat pemerintah, dan/atau masyarakat harus memberikan perlindungan terhadap anak baik tindakan kekerasan fisik, psikis, kejahatan seksual, dan kejahatan lainnya di lingkungan sekolah dan masyarakat. Perlindungan hukum ini diharapkan memberikan rasa takut anak untuk tidak melakukan tindakan bullying kepada teman dan jika melihat kejadian bullying di lingkungan sekolah anak bisa melaporkan kepada pihak sekolah. Sehingga di lingkungan sekolah kejadian-kejadian bullying ini bisa diminimalisir dini. 


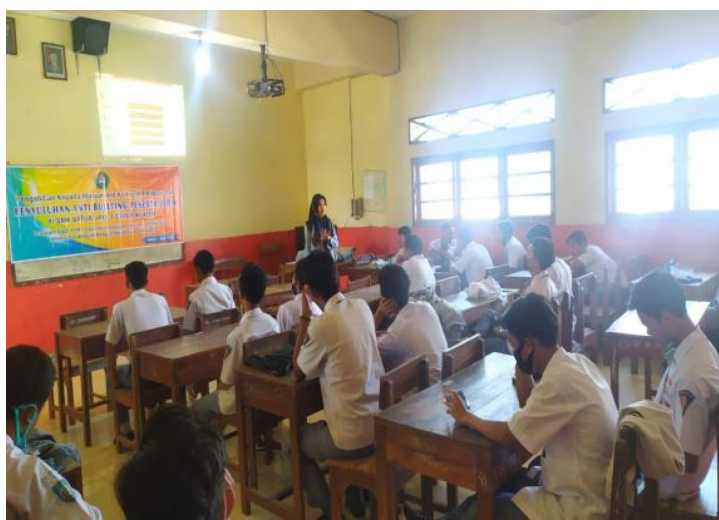

Gb. 2 Foto Kegiatan Tanya Jawab

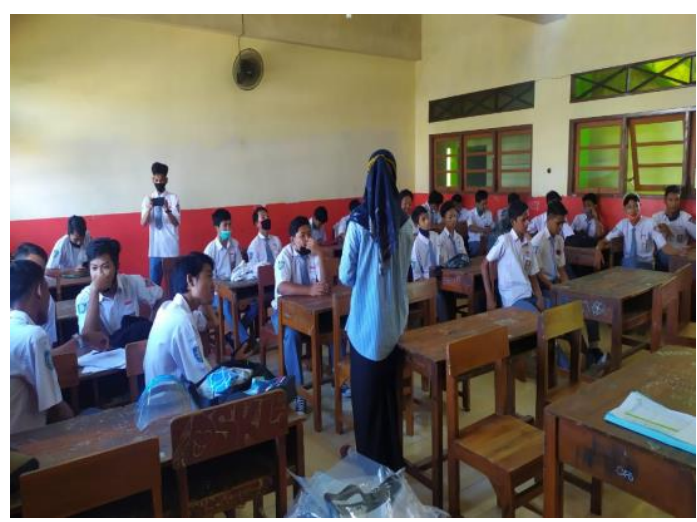

Gb. 3 Foto Kegiatan Post Test

Pada kegiatan post test juga ditayangkan film video tentang bullying, kemudian peserta didik menganalisis dan memecahkan solusi yang dialami. Kegiatan ini ditunjukkan keaktifan peserta didik dalam mendiskusikan dan tanya jawab sebesar 9 peserta dari jumlah 30 peserta yaitu $30 \%$. Keaktifan ini menunjukkan suatu respon positif peserta didik terhadap kejadian bullying yang harus dihindari. Sebab sebelumnya, peserta didik kurang aktif dan tidak ada yang bertanya dan mau mendiskusikan masalah-masalah bullying. Dari tanggapan peserta didik tersebut, tampak peserta didik peduli terhadap korban bullying dan memberikan pemecahan bahwa kejadian bullying tidak seharusnya terjadi di kelas demi kerukunan antar teman. Kepedulian yang tinggi diharapkan dapat meminimalisir kejadian mereka sebagai pelaku ataupun korban, sehingga kasus bully tidak memunculkan masalah-masalah yang berdampak pada fisik dan psikiologis anak.

Berdasarkan post test dan pengamatan langsung menunjukkan bahwa pertama, peserta didik mengetahui secara mendalam mengenai bullying, kategori, penyebab, dampak dan strategi mengatasi bullying. Sehingga ada perkembangan pengetahuan dan tata cara mengantisipasi terjadinya bullying. Kedua, mempunyai keterampilan dalam menghadapi kasus-kasus bullying. Ketiga, mempunyai keberanian untuk menceritakan kasus bullying yang dialami teman dan orang sekelilingnya. Keempat, mempunyai wawasan mengkategorikan kasus bullying sehingga berani melaporkan kepada guru dan orang tua, bahkan pihak polisi. Kelima, memberikan masukan kepada pihak sekolah bahwa perilaku-perilaku bullying yang terjadi di lingkungan sekolah perlu ditangani secara serius oleh guru Bimbingan Konseling di sekolah, sehingga guru dapat melakukan pencegahan dan intervensi secara tepat pada anak yang memiliki perilaku bullying. Dengan demikian, setelah dilaksanakan penyuluhan anti bullying, maka terjadi peningkatan pengetahuan menjadi $85 \%$. Perilaku-perilaku agresif berupa tindakan bullying ini harus terdapat sinergitas pengawasan dari orang tua, guru, dan masyarakat. Pengawasan dan pendampingan secara berkelanjutan dapat meningkatkan rasa aman dan nyaman anak, sehingga mereka dapat beraktifitas seperti biasa tanpa ada tekanan dari siapapun.

Berdasarkan hasil dan pembahasan di atas, maka penyuluhan anti bullying di SMK Batur Jaya 1 Ceper Klaten dapat dikatakan berhasil, karena ada peningkatan pengetahuan mengenai bullying. Hasil pre test menyatakan bahwa pengetahuan peserta didik mengenai bullying sangat minim yaitu $30 \%$. Sedangkan hasil setelah dilakukan post test, maka pengetahuan peserta didik meningkat menjadi $85 \%$. Keberhasilan ini dapat diukur dengan banyaknya peserta didik yang mau dan berani bertanya dan memecahkan masalahnya, serta juga bisa dilihat dari kepuasan peserta setelah mengikuti kegiatan, sehingga memotivasi peserta didik untuk menghindari dan tidak melakukan tindakan bullying di sekolah. 


\section{SIMPULAN}

Penyuluhan anti bullying di sekolah merupakan langkah tepat untuk memotivasi dan memberikan informasi mengenai anti bullying kepada peserta didik. Efektifitas kegiatan tersebut tampak aktifitas peserta didik mempunyai pengetahuan yang luas dan berkeinginan untuk mengimplementasikan dengan menghindari perilaku-perilaku agresif yang dilakukan oleh orang di sekelilingnya. Dengan demikian, dapat meminimalisir kejadian bullying yang terjadi di Indonesia secara umum dan di sekolah secara khusus. Sebab perilaku-perilaku bullying jika dibiarkan dapat menyebabkan penurunan semangat belajar, tingkat kriminalitas tinggi, tekanan mental yang mengakibatkan depresi, dan tindakan bunuh diri. Perilaku bullying juga dapat dikenakan sanksi hukum bagi yang melanggarnya.

Kegiatan penyuluhan anti bullying ditunjukkan keaktifan peserta didik dalam mendiskusikan dan tanya jawab sebesar 9 peserta dari jumlah 30 peserta yaitu 30\%. Secara keseluruhan kegiatan penyuluhan anti bullying di SMK Batur Jaya 1 Ceper Klaten dapat dikatakan berhasil, karena ada peningkatan pengetahuan mengenai bullying. Hasil pre test menyatakan bahwa pengetahuan peserta didik mengenai bullying sangat minim yaitu $30 \%$. Sedangkan hasil setelah dilakukan post test, maka pengetahuan peserta didik meningkat menjadi $85 \%$. Hasil kegiatan ini yaitu banyaknya peserta didik yang mau dan berani bertanya dan memecahkan masalahnya, serta juga bisa dilihat dari kepuasan peserta setelah mengikuti kegiatan, sehingga memotivasi peserta didik untuk menghindari dan tidak melakukan tindakan bullying di sekolah.

\section{UCAPAN TERIMAKASIH}

Penulis mengucapkan terima kasih kepada pihak yang telah memberi dukungan dana pelaksanaan Pengabdian kepada Masyarakat Kompetitif Bidang IImu yaitu LPPM Universitas Veteran Bangun Nusantara.

\section{DAFTAR PUSTAKA}

Djuwita, R. 2006. "Kekerasan Tersembunyi di Sekolah" : Aspek -Aspek Psikososial dari Bullying. www.didplb.or.id. (online). Diakses, 10 Oktober 2020.

Kartono, Kartini. (2003). Patologi Sosial: Gangguan-Ganggaun Kejiwaan. Jakarta: RajaGrafindo Persada.

Migliaccio, T., \& Raskauskas, J. (2016). Bullying as a Social Experience: Social Factors, Prevention and Intervention. Oxfordshire: Routledge.

Putri, H.N \& Nauli, F.A. \& Novayelinda. R. (2015). Faktor-Faktor Yang Berhubungan Dengan Perilaku Bullying Pada Remaja. JOM. Vol 2 No 2.

Rosen, L. H., DeOrnellas, K., \& Scott, S. R. (2017). Bullying in School. Diakses dari: https://doi.org/10.1057/978. Tanggal akses: 20 Maret 2020.

Schneider, SK, O'Donnell, L, Stueve, A, and Coulter, RWS. (2012). Cyberbullying, School Bullying, and Psychological Distress: A Regional Census of High School Students. Diakses dari: http://search.proquest.com/docview/1004790733/fulltextPDF/13CE1C43CEA7E55BA 0D/37? accountid=32506. Tanggal akses: 20 Maret 2020.

Sejiwa, (2008). Bullying : Mengatasi Kekerasan di Sekolah dan Lingkungan Sekitar Anak. Jakarta: PT Grasindo.

Undang-Undang Nomor 23 Tahun 2002 tentang Perlindungan Anak sebagaimana telah diubah oleh Undang-Undang Nomor 35 tahun 2014 tentang Perubahan Atas Undang-Undang Nomor 23 Tahun 2002 tentang Perlindungan Anak. 
Veenstra, R., Lidenberg, S., Winter, AF., Oidehinkel, A. J, Verhulst, F.C., Ormel,J. (2005). Bullyingg and Victimization in Elementary Schools: A Comparison of Bullies, Victims, Bully/Victims, and Uninvolved Preadolescents. Developmental Psychology. 41,4,672682. 